\title{
FROM MODERATISM TO FUNDAMENTALISM; \\ Portrait of Shifting the Religious Understanding of Makassar Islamic Students
}

\author{
Syamsurijal \\ Researcher at Litbang Agama Kemenag Makassar \\ Email: ijhalbatigol@yahoo.co.id
}

\begin{abstract}
Students have been asked as intellectuals who have high critical power. Therefore students are not only a driver of a social change, but at the same time are not easily influenced or participate in certain currents of thought and understanding, especially if it is related to religious understanding. Students' critical attitude becomes a kind of filter to sort and filter out various religious ideas and ideas. But the view that sees students, especially Muslim students as a critical group, seems to be faltering lately. Instead of being a critical community group with a variety of new religious understandings, Muslim students actually became the target of the new Islamic doctrine of religious understanding. The doctrine of religious understanding is precisely textualism and fundamentals. This qualitative research shows that several large campuses in Makassar were exposed to the Islamic understanding and changed them from moderate Muslim students to Muslim fundamentalist students.
\end{abstract}

Keywords; Social Change - Critical - Doctrine - Textualism - Fundamentals

\section{Introduction}

The process of globalization does not only obscure the boundaries between countries, but also facilitates the 
movement of ideology and ideology from one country to another. Key Deaux and Shaun Wiley in Gail Moloney (2007), once mentioned the existence of moving people and shifting representations in the context of globalization. Where there is a movement of a group of people from a particular country or place to another place. This process will result in population changes in one place, which in turn shifts people into representing their religious understandings.

Moreover, Woodward (2007) states that moving people and shifting representations are not merely movements of groups of people but also moves or enters new understandings or ideologies into certain countries, especially religious understandings.

The movement of this global ideology passes without national bases, nor does it recognize the concept of nation state. Its movement crosses national borders. Often this movement also attempts to influence political policy in a country, its purpose is not for the interests of this nation itself but rather for global interests. In the national domain, for example, there is an effort to push for certain religious ideas as the basis of the state. There are demands to change the Pancasila and the 1945 Constitution as a state constitution.

At the cultural level the movement to change the religious understanding of the community takes place systematically, through education, law, study groups, economic movements, da'wah and training. Unfortunately, this movement turned out to target more to young people. 
The students became one of the softest elements brewed in such a way as to change their religious understandings.

Students are crammed with certain religious understandings in regular formation and discussion. They are presented with readings about Islam, both in the form of bulletins and books, which show a different understanding of religion than what they have understood so far. They finally understand religion, other than what has become the mainstream understanding of Islamic students so far.

In the past, among students who flourished were Islamic religious understandings of Ahlusunnah wal pilgrims developed by $\mathrm{NU}$ and Muhammadiyah. The religious understanding is represented by organizations such as PMII, HMI and IMM. This kind of religious understanding can be seen in the religious attitude of students who are tolerant and respectful of Islamic treasures, appreciate tradition and also love for the homeland.

Now what is rife is the emergence of Islamic organizations, where their religious representation far refers to the country. Crossing national borders. This is what led to the emergence of new religious ideas among Islamic students. They represented themselves in the Campus Da'wah Institution, Haraqah with various names, and Student Action Committees. They also appear in the form of regular public discussion and study. The issues that emerged during the various discussions were religious issues that were more radical and extreme. 
This was reflected in the research of Makassar's R \& D Religion in 2010 about student religious understanding. In the study it was illustrated; more than $60 \%$ of Islamic students agree to encourage the application of Islamic law or formalization of religion (Research on $\mathrm{R} \& \mathrm{D}$ of Religious Understanding, 2010). It did not stop there, many students began to lose pride in Pancasila and the shape of the Indonesian state today. They began to promote the emergence of Khilafah Islamiyah. This shows the purpose they are fighting for is not a homeland but something that is transnational.

\section{Perspective in Seeing Problems The Shift of Religious Understanding}

In the current context of globalization, the country's barriers are becoming increasingly blurred. This facilitates the understanding of economics, politics, theory, ideology, technology and also the various understandings of countries in the world crossing borders. Globalization inevitably gives birth to a model of nation, state, ideology and even religion that is no longer single, but increasingly diverse.

Globalization also encourages cosmopolitanism, but at the same time there is a strengthening of identity that bases itself on communalism and traditional social institutions. If globalization offers a variety of new ideas that are produced from the outside, then the one-nation society tries to look for a representation of itself on something local. This is what Ulrich Beck calls a contradiction of globalization. This indeed 
has resulted in a shift in society in representing themselves, but insofar as this can be managed, what is being done is usually a positive thing. Here comes the new citizenship concept that accommodates locality. For example in religion, religion re-develops with the color of its locality.

It's just lately as stated by Key Deaux and Shaun Wiley in Gail Moloney (2007); the movement of a group of people from one country to another is more massive. This, according to Woodward (2007), systematically changes ideas in certain countries because there are indeed actors who carry the agenda. Moreover, this process is strengthened by increasingly powerful information technology.

In Indonesia this is felt in the context of religious understanding. Where at this time, very easily various religious ideas infiltrated and influenced Indonesian society. These religious understandings, especially if we observe them in Islamic society, have fostered the birth of various new schools.

The process of doctrine of these new Islamic religious understandings is carried out through da'wah and education. Da'wah is carried out in mosques, while education is carried out through schools and campuses. In the world of education this is the process of doctrine of new religious understandings that easily occurs. The shift in religious understanding also stood out among students and students.

The shift in religious understanding in this context is more likely to be seen as a deliberate and systematic process carried out by certain groups. The goal is indeed to change the 
religious understanding of the community (in this case students). The goals to be achieved are not for the benefit of our nation and homeland, but rather for the agenda of certain groups which usually exist in other countries. This shift in the pressure point is not in the context of constructive meetings or dialogues between the global and the local which gave birth to glocalization, but purely as an infiltration of certain organizations and groups in Indonesia to change our religious understanding. Because of this the shift in religious understanding usually does not give place to the traditions of the archipelago and also does not respect the opinions of local scholars from this archipelago.

\section{Fundamentalism-Radicalism}

The term fundamentalism is actually problematic to use. This is because fundamentalism can mean fundamental and profound religion. In this context all adherents of religion need that attitude. Some figures use other terms to replace this word fundamentalism. Khaled Aboe al-Fadl prefers to use the word puritanism (El Fadl, 2005), to designate Islamic groups who are considered to have an absolutism view and without compromise. Some other thinkers use different terms. Gilles Kivel and Emmanuel Sivan used the term 'radical Islam' (Sivan, 1990). There are also those who use the terms integrism, revivalism and Islamism.

The term Fundamentalism appeared in 1909 after 12 Minutes were spread throughout the world. The treatise entitled The Fundamentals was compiled by Christian 
Evangelik (Khaled Abou El-Fadl, 2005). These words of fundamentalism came to prominence when they first appeared in The Shorter Oxford English Dictionary in 1923. The term that emerged at the beginning of the 20th century was a framework of conservative Protestants in America, to show the doctrinal characteristics based on the gospel (Rumadi, 2009).

There are five points that become the views of the conservative Protestants, namely the birth of Jesus from the virgin, his physical resurrection, the gospel without fault, the atonement of sin and the second coming of Christ. If this is then pinned to Islam, then only one part of the five points may be the same, namely the matter of the gospel - in Islam of course the Qur'an - which is never wrong.

But to understand what is meant by fundamentalism, the most important thing is to understand the patterns of movement. This pattern, as revealed by Martin E. Marty, which was revealed by Karen Armstrong (2005), can be summarized as follows:

The first way to worship religious texts is textual and monopolize religious interpretations. Both are intolerant of the different. Therefore they can commit acts of violence or approve these actions. Third, rejecting modernity, especially the concept of concepts related to the appreciation of diversity. Fourth, they carry out political power movements. Fifth ; Do not believe in the concept of the Unitary State of the Republic of Indonesia and the Pancasila as the basis of the State. 


\section{Map and Development of Islamic Student Religious Organizations in Makassar}

Makassar Municipality is one of the most cosmopolitan areas in Indonesia. In the ranks of major cities, the city is included as the fourth most populous and most crowded city in Indonesia. It can even be said that this city is being or at least one step away from being a metropolitan city. This is marked not only by a variety of skyscrapers, but also with a variety of people who live and move in it. The colors are reflected in the tribe, language and religion that live in this city.

In terms of religion, from Islam to Konhuchu, it is in this city. If you observe the organization, especially in internal Islam, there are various forms. You can easily find NU and Muhammadiyah, the dominant organizations in this city. You will also have no difficulty in finding organizations such as Hisbut Tahrir, Wahdah Islamiyah, Ahmadiyya and even IJABI (Association of the Ahlu Bait Indonesia Jamaah) and ABI (Ahlu Bait Indonesia) which have been considered as a Shiite cult. If we observe in terms of ethnicity and language, then in this city also live various tribes. There are Javanese, there are Sundanese, Bataks, Ambonese, Papuans, Betawis, Chinese, Indians and many others.

For the eastern part of Indonesia, Makassar is also considered a center for the development of science. Universities in the regions stand in various places. Starting 
from colleges in the form of Colleges, the Institute to the University is growing rapidly in this city. Universities that are considered to be quite large and influential in Eastern Indonesia are also present in this area, such as UNHAS, UNM, UIN, UMI and UNISMUH. With the large number of universities in this area, there is no doubt that the religious organizations of students, especially those based on Islam, have become the arena of growth.

Post-reform, Islamic-based student organizations are growing rapidly in Makassar. If previously only known as the Islamic Student Association (HMI) group, the Indonesian Islamic Student Movement (PMII) and also the Muhammadiyah Student Association (IMM), then the period after reform, other organizations also began to develop. The development of a dynamic Islamic organization on campus other than because of freedom of association and expression has gained wide space, also because during the new order of the Islamic groups who felt depressed, they could now stretch again. The lack of space for Islam in the new order was recognized by one of the KPPSI leaders:

From the time of the Independence of Indonesia, the ideology of development which was always imbued by communism (the period of the Soekarno), capitalism (the Soeharto period) and period nationalism (Habibie, Gusdur and Megawati), all of them did not bring this nation to a better place. While Islam was not given the slightest opportunity to regulate this nation, except materially beneficial ones, namely the problem of zakat and hajin (Aswar Hasan, 2002). 
The previous group that moved more quietly, now appears more expressively. Transnational Islamic groups such as HTI, Salafi groups, Wahabi groups, Shiites began to wriggle on campus. An internal campus institution such as the Campus Da'wah Institution, which used to be not active in activities, is now starting to stretch again. This LDK even on several campuses appeared with the names of study clubs to various Islamic countries. In addition to the previous groups that began to show their activities, there were also other emerging Islamic groups and organizations. One of the newly emerging is the salafi group that operates in the organization of the Mushallah Lovers / Mosques Students.

The emergence of new organizations and understandings among Islamic students in Makassar does not automatically change the religious understanding of students in this area, but this is not the case in campus institutions. Slowly but surely this new understanding began to dominate Islamic understanding in various campus student organizations in Makassar.

\section{Map and Shift of Religious Understanding of Islamic Students in Makassar}

\section{UIN Alauddin Makassar}

Alauddin's State Islamic University (UIN), formerly known as IAIN Alauddin Makassar, is one of the well-known Islamic student campuses in Eastern Indonesia. As one of the Islamic labeled campuses, of course in this place various Islamic organizations have developed. Islamic organizations 
that have long existed on this campus are the Islamic Student Association (HMI), the Indonesian Islamic Student Movement (PMII) and the Muhamadiyyah Student Association (IMM). At the beginning of the existence of the IAIN, (which has now turned into a UIN) this organization has developed quite rapidly.

Post-reform, Islamic organizations that developed on this campus were not the only three organizations, but other groups of Islamic students had emerged. The Campus Da'wah Institution (LDK), then the Lovers of the Mosque / Mushallah which was assisted by Wahdah Islamiyah, the Association of the Ahlul Bait Indonesia (IJABI), Ahlul Bait Indonesia (ABI) and also Hizb ut Tahrir began to color the map of Islamic organizations among UIN Alauddin students.

Actually the emergence of new Islamic groups or organizations among UIN students has occurred since the late 1990s. Even since the beginning of the 1990s, new Islamic ideas that have aroused Shiite thinking have developed on this campus. This was influenced by the Iranian revolution with its character Khomeini. At that time Ali Shariati's books, Murthada Muttahhari who were considered revolutionary had become student reading material. However, in those days students only made it as a critical knowledge material. The religious understanding of students has not been significantly affected.

Precisely around 1995 Islamic organizations began to show themselves on campus. At the point of prey, often Hizb ut-Tahrir participated in various Islamic seminars. In fact, 
they have also begun to carry out various small discussion activities. However, the existence of this group did not emerge from the surface, covered by the frenzied three major Islamic organizations at that time; PMII, HMI, IMM.

Post-reform, the new Islamic organization began to be active with various activities. The process of cadre recruitment begins. Religious discussions began to be intensified on campus. Campus mosques become the arena that is most often used as a place for discussion.

At present, religious organizations on the UIN campus are increasingly diverse. This diverse group of groups began to show its existence. Nevertheless the dominant color is still dominated by PMII, HMI and IMM. One of the campus students gave an illustration that in one class of lectures from various religious organizations, almost $50 \%$ of them were confirmed if they were not PMII, HMI had to (interview, Kasim, 2015). The third sequence of the largest Islamic student organizations on this campus is IMM. These three organizations because they are quite large on the campus of UIN, it is necessary to give a glimpse of their character and religious understanding. This description is limited only to religious understandings that are the focus of this research; that is; Theology and several rituals, the religious traditions of the Nusantara Islam, the understanding of nationality in relation to religious (Islamic) and State relations, and the question of religious plurality.

First; HMI. This Islamic Student Organization was founded on February 5, 1947 with a basic idea; Maintaining 
the Unity of the Republic of Indonesia and developing the Islamic faith. From there it is clear that the HMI in the matter of nationality did not question the form of the State of Indonesia. In fact, there is clearly a strong desire to defend this unitary State. But the desire to make Islam as a value base in managing this country has never been lost in the organization. This includes the students at Alauddin UIN.

Indeed, among UIN students a secularization discourse has emerged. This idea developed after one of the leaders and former chairman of the HMI; Nurcholis Madjid echoed this discourse. Indeed, this idea if associated with the discourse of religious-state relations is a process of separation of religion and State. In this understanding the State does not deal with religious matters, and at the same time religion cannot enter the State. Religion is an individual matter of society. But in the hands of secularization Nurcholis is not in this meaning. Instead of referring to the definition of secularization as the separation of religion and State, Madjid even hinted at the ideology of Islam in the State. Then how does he provide the definition of secularisation. After first distinguishing the word secularism and secularization, he chose secularization in the sense of Robert Bellah and Talcot Parson, namely freeing society from superstitions in aspects of life. In short the secularisation is to make worldly things as worldly and not mix with the problems of the hereafter. With this idea, Nurcholis was actually affirming the idea of Islamic purification (Nurcholis, 2007). 
Because the idea of seculurization is not the separation of state and religion, then in the context of the nationality of HMI activists in UIN nothing has changed. The tendency of the ideology of Islam in the State is still a trend. Then what about the idea of renewal or purification of Islam and also the liberalization of the Nurcholis style. In the 90s, UIN HMI children were quite amazed by this idea. but in the scope of UIN (IAIN at that time) it was not sufficiently absorbed. Moreover, among the HMI activists at UIN they were also children of boarding schools, so that their religious attitudes and understandings remained within the framework of Islamic traditionalism. In such an Islamic framework, the UIN HMI does not become an anti-religious celebration that is thick with traditional nuances, and even becomes part of the tradition. Even in the era of the 2000s, HMI activists did not care much about the development and renewal of Islamic thought.

So how does the attitude of the few activists of the HMI UIN towards religious diversity appear to be in certain situations where there is a tendency to be slightly exclusive and reactive. In responding to the Ambon riots in 1999, for example, at that time many HMI activists took to the streets in front of people who were considered Christians. But overall this attitude does not characterize the UIN HMI. Generally HMI activists are a group of students who hold the principle of tasammuh (tolerant) and tawasuth (moderate). Moreover, Qashim Mathar, one of the HMI seniors in Makassar who 
happened to also be a lecturer at UIN, was a figure who was keen to fight for pluralism in South Sulawesi.

Second; Muhammadiyah Student Association (IMM). This Islamic Student Organization is clearly part of the Muhammadiyyah. Of course the religious principles carried out are not very different from the parent organization, Muhammadiyah. If initially this religious organization was considered anti-tradition and did not accept religious treasures which were not considered to be pure Islamic teachings, then after 2004 when the emergence of cultural da'wah policies from Muhammadiyah, IMM began to appreciate the growing religious traditions in the community.

A tolerant attitude towards the traditions of the community also began to develop. In the matter of nationality, in relation to the relationship between Islam and the State, the UIN IMM also does not question the current form of the State which is not in the form of a religious State. Even though Amin Rais echoed earlier the discourse about structural Islam, this discourse did not intend to change the shape of the State into a religious state. Moreover IMM UIN activists do not respond to this kind of discourse. Including when before the 2000s among Muhammadiyah young people emerged the JIMM (Muhammadiyah Young Intellectual Network) group which was quite liberal, the UIN IMM also did not respond to the discourse. In general, IMM at UIN is a tolerant group of students. The puritan and modernist image that has been attached to Muhammadiyah, is not too prominent in UIN IMM students. 
Third; Indonesian Islamic Student Movement (PMII). PMII was initially an NU underbow student organization, but in the Munajati declaration this organization stated that it was not organizationally bound with NU. Nevertheless PMII also did not withdraw the demarcation with $\mathrm{NU}$, still in religious understanding and behavior as well as culture following NU. In fact, this organization states that it will always be devoted to the Ulama in NU. From here it is clear that PMII's religious understanding is certain to be Ahlusunnah waljamaah. The principles of tawasuth, tasammuh, and taaddul are inseparable parts of their religious life.

PMII UIN, mostly from santri and kampong backgrounds is thick with religious traditions. This student group is accustomed to maulidan, barazanjian, tahlilan, ziarah pilgrimage and other salvation events. In the matter of religious-state relations, the UIN PMII activists are of course in tune with NU, especially with the concept of Gusdur, that the State of Indonesia is now undisputed. Religion becomes the source of values and ethics in the state but does not have to be formalized into the State. Therefore, PMII UIN activists never agreed with the issue of religious formalization, especially the issue of khilafah.

PMII activists at UIN in the late 1990s, have also been concerned with leftist discourses as well as progressive Islamic thought. This kind of intellectual color is still coloring the activists to date, although it is no longer the dominant color. Although the interest of activists from the PMII UIN on left studies and post-structuralist-postmodernist studies is quite 
high, their religious understanding and behavior still remains in Aswaja's frame. Still these activists carry out their religious habits so far. There is a strong impression, their studies of the discourse mentioned earlier, actually serve as the legitimacy of knowledge of their religious behavior.

Other organizations or groups of students in UIN that began to develop such as Hizb ut-Tahrir, Loving Students of Mushallah, IJABI, KAMMI, and Tarbiyah, Gusdurian will be described later in the sub discussion of the shift in religious understanding of UIN students.

\section{Shift in Religious Understanding; Still Faint and Slow But ...?}

As described, after post-reform, a group of students developed outside the three major organizations of HMI, PMII, IMM. The groups or organizations include, Hizb utTahrir, MPM, IJABI, KAMMI and Tarbiyah. The Gusdurian group also last developed, although this group did not bring new understanding at all. Gusdurian, only continuing the religious ideas of Gusdur, which, of course, as we understand, will not be very different from NU's ideas. Moreover, among them dominant were PMII activists as well, added HMI children, and a handful of IMMs. Therefore, even though it is new, it does not bring new religious understandings (Interview Suaib, 2015).

This is certainly different from groups such as HTI, KAMMI or MPM and Tarbiyah groups. These organizations bring new ideas that are different from previous 
organizational understandings. Of these new organizations, Hizb ut-Tahrir was clearly an organization from the outside and then entered Indonesia. While others, although formed within the country, but have an outgoing network, especially in matters of religious understanding. Because it originates or has a network out (outside Indonesia) this is what causes their religious understanding to be different from organizations such as HMI, PMII and IMM.

Hizb ut-Tahrir has a specific and slightly foreign understanding of diversity in the Student's religious discourse, namely the matter of khilafah. This shows that in the context of relations between religion and State, they want Indonesia to become an Islamic State. In fact, the concept offered instead removes the current form of the State and becomes a part of the international caliphate (Syarifuddin Jurdi, 2008). This thought which was initiated by its founder Taqiyyudin Annabhani wanted a caliphate system that ruled all Muslim regions as a religious obligation and basically was the Koran and hadith (Taqiyyuddin, 2007).

This kind of understanding certainly eliminates what is called a nation state. All ideas that are considered western, such as democracy and pluralism are also rejected outright. Even in various campaigns that he did, those understandings were regarded as the culprit of this nation's downturn (interview Fahrul, 2015).

In the matter of religious traditions that are commonly practiced in Indonesia, this HTI group does not really bother. Their concern is how to form the Caliphate and 
replace the current state model. However, when viewed from the teachings of Taqiyyuddin, it is possible that in time this group will want the purification of Islam. Moreover, religious celebrations in Indonesia and the development of various Islamic groups are considered as a western conspiracy against Islam. This was acknowledged by some of his activists at Alauddin UIN that the existence of religious celebrations such as mauled prophets was actually only western engineering to make Muslims busy with rituals that were not clear but forgot politics (Fahrul, 2015).

Another group, the Mushallah Loving Students also developed a different understanding from the previous student group. The most characteristic of the religious understanding of this Student Lovers of Mushallah who is an affiliate of Salafi Wahdah is his attitude and views that reject all religious traditions that are prevalent in society, such as maulid, the tradition of pilgrimage, tahlilan. Besides that they tend to reject other groups who differ in their views, especially those which are considered to be smelling of tasawwuf. The tendency to reject the model of interpretation of Islam except textually also colors the perspective of this group.

Of the two groups presented with this understanding of diversity (others not too prominent in UIN), it appears that there is a tendency for understanding that leads to fundamentalism. If we follow the path of Karen Armstrong who follows E. Marty's view of fundamentalism, then some preconditions of religious fundamentalism can be seen in the perspective of student activists who were members of the two 
groups of students. Refusing ideas that are considered modern, monolithic tapsir, rejecting the religious understanding of other groups, and using political channels of power in their movements (especially HTI) (Armstrong, 2005).

Then what is the influence of such organizations on UIN students? Is this group able to influence students' religious understandings so that their colors are now changing?

If viewed as a whole, even though it began to develop but it has not been able to shift the understanding of student affairs on this campus. One reason is because many of the UIN students are pesantren alumni. This was stated by the deputy dean III of the faculty of Ushuluddin: "On campus, especially in the faculties of religion, like ushuluddin, there is a lack of development of organizations such as HTI and the ideals that are adopted. (Interview with Abd Wahib, 2015). This, according to Wahib's statement, was because Ushuluddin students, who had attended most of them, had a good understanding of religion.

But the wings of the HTI group (Chapter HTI and Gema Pembebbasan) and Salafi-Wahdah tried to build their movements in public faculties, such as the Faculty of Science and the Faculty of Public Health. In this place they slowly began to shift the religious discourse that had been developed by PMII, HMI and IMM. Even in this place they can recruit cadres. In addition, they also strengthen their discussion both in the mosque or the courtyard of the mosque. 
HTI for example, this group has a regular schedule for discussions; every Thursday for the brothers through Gema Pembebasan and Friday for HTI Muslim women (MHTI) (Sari interview, 2015). At certain times, HTI usually holds seminars with issues that are considered actual. In addition, they are also diligent in holding discussions at boarding houses. The echo of liberation usually takes on themes of anticapitalism and imperialism. This discourse is favored by students because critical and leftist impressions stand out from this kind of theme. From this kind of discussion, if anyone is interested, it will be continued in the further cadre process. Through this discussion and seminar the recruitment arena began. Of course the interpersonal relations between HTI students and certain students are also one of the ways in the recruitment.

It can be said that in the matter of religious studies at this time HTI through its Gema Liberation was increasingly prominent in UIN Alauddin. While PMII and HMI and IMM, although they often held discussions, they were not routine. The salafi-wahdah group, though also held discussions at the campus level, was not too prominent. They do more of a kind of guidance about religion to their members or interested students. This group actually sought to enter the Campus Da'wah Institution and run the agenda from there. In the LDK itself other groups or organizations were also entrenched there such as IMM, and a handful of PMII and HMI. So that in LDK, they understand that they don't become dominant (Interview with Fadli, 2015). 
This at least shows that groups such as HTI and salafiwahdah have indeed begun to show their existence on the UIN campus. Indeed, it has not massively influenced and shifted the religious understanding of students, but began to fill empty spaces such as discussion rooms, mosques and also in the LDK. This salafi-wahdah group has also built crosscampus networks in the Salaf Study Group. This group is not merely a study, but also a means to gather to design strategies to recruit salafi cadres on various campuses. This will be more clearly seen in the subsequent discussion about UNM and the Shift in Religious Understanding of the Students.

\section{Makassar State University (UNM)}

UNM is one of the major universities in South Sulawesi, even East Indonesia. The students come from various regions in Eastern Indonesia. On this campus also developed various student organizations both intra and extracampus. Especially for Islamic Student organizations, the development is quite significant. Organizations such as HMI, PMII, IMM, HMI MPO, IJABI and other Islamic student organizations are quite developed.

Newly developed organizations include HTI and the echo of his release, the Salafi-Wahdah group, KAMMI, and the Shia Student Group. In addition there are also several Islamic study clubs and LDK campuses, both of which are part of intra and extra campus organizations (Interview with Prof. Rifdan, 2015). 
HMI, PMII, IMM, HMI MPO is an old organization whose religious beliefs are mainstream religious understandings in Indonesia. In the matter of nationalism, tradition and religious understanding, this organization is the same as what has been described in the previous UIN.

The MPO HMI had once stated that their principle was Islam, but in the matter of nationality, they had never questioned the State of Indonesia at this time. The MPO is also tolerant of different understandings, including even religion outside Islam. Modernist ideas were not questioned by this group at UNM. Of course they were critical of modernism, but not in extreme opposition.

While the good Shia student groups who are members of the IJABI (the Association of the Ahlul Bait Indonesia Jamaah) and the ABI (Ahlul Bait Indonesia) certainly have different religious understandings than the Student organizations mentioned earlier whose basis is Sunni. But this Shia student organization is not antipathic towards various religious traditions that are prevalent in Indonesia. Most religious traditions are even practiced. Even though Shia knows the Imamat leadership system, but in the context of Shia students at UNM, it is not an important issue. They do not question the Indonesian leader and the current government system. This student group is also quite tolerant of what is different from them especially towards the Sunni community. Even this group is active in discussions in groups across Islamic and interfaith organizations. 
Other Islamic Student Organizations at UNM are HTI (with MHTI and Student Movement for their release) and several LDK in the form of study clubs. The latter is part of an intra-campus organization. The club's study groups include: Maipa Muslim Study Club (SCMM) at the MIPA faculty, Student Da'wah Center (PUSDAM), Raudhatul Mujaddid at the Faculty of Engineering, Club al-Ikhlas study at the Faculty of Arts, Raudhatul Ni'mah Study Club at the Faculty of Education, Al Furqan (Faculty of Social Sciences), Al-Huda at the Faculty of Economics, and Arriyadah at the Faculty of Sports.

At the university level there is the Islamic study forum Raudhatul Ilmi and the Institute for Scientific Scientific Student Studies (LKMIB). Raudhatul Ilmi is an LDK at the campus level which is an extra organization, while LKMIB is the official LDK campus. Besides that HTI also established LDK at the campus level with the name of the Contemporary Islamic Studies Forum (LDK FOSDIK) (interview Ardilla, 2015).

Student groups from HTI (MHTI, GEMAPEM, LDK FOSDIK) understand the diversity described earlier and there is no difference for UNM. For the UNM context the process of disseminating their ideas also continued with studies, seminars, publishing and disseminating bulletins and magazines. Through GEMAPEM they put forward the ideas of anti-imperialism and all understandings that were considered to smell western. 
The official university level LDK is LKIMB colored with various groups and Islamic understandings. But this LKIMB religious style and understanding is more colored by moderate ahlussunna wal jamaah. In this organization the appreciation for diversity was prominent, this was acknowledged by its chairman Hery (interview, Hery, 2015). This group has a foothold or guideline called Kitab Hijau. This is the basis for organizing with the principles of respect for plurality (interview Baihaqi, 2015).

Although there are radical-fundamentalist groups in this LKIMB, they cannot do anything. The existence of the Kitab Hijau makes them have to follow the rhythm of the organization. This study group also never questioned the understanding of nationality and the shape of the State of Indonesia today. Thus the style and understanding of the diversity of students belonging to this dominant group is not too different from other groups such as HMI, PMII or IMM. But because of this LDK at the university level, there really isn't much contact with students in the faculty. So that their religious character and understanding are not dominant in influencing students.

The Islamic Student Study Group or LDK which is actually influential in the faculties, is a group that is indeed officially available in each faculty. The study group, as mentioned earlier, did a lot of guidance for students in religious matters. This group is seen as coloring religious understanding in students, especially in the Faculty LDK level. This group also made a kind of LDK at the University 
level under the name Raudhatul Jannah Study Forum. This is done because the official LDK is LKIMB, they cannot control it.

\section{The Role of Study of Islamic Club at the Faculty Level in Shifting the Religious Understanding of Students}

The club study group at the faculty is official and is under the auspices of the Faculty Student Executive Board (BEM). So this club study is like a faculty level Da'wah Campus (LDK). His main task is to assist the University in fostering UNM students, most of whom come from public schools, in the religious field. Activists from this group usually help students learn Alquraan and teach the basics of practicing religion. These faculty club study activists were favored by faculty or university officials. In addition because they helped foster students in the religious field, this group was considered not willing to be involved in student brawls, including in various demonstrations. For campus officials, of course the religious understanding of a particular organization is not important, what is significant is whether the organization can help campus development or not

In the SAINS program (Intensive Qur'anic Study) which is a part of religious learning on the UNM campus, many faculty activist study clubs are involved as tutors. Even though the tutor is actually open to all senior Muslim students but there are a number of conditions: The GPA must be good, never anarchist demonstrations or brawls and never commit legal violations (Interview with Prof. Rifdan, 2015). 
This requirement can be fulfilled by club study activists who are of the type of religious acupuncture students.

Through SCIENCE, these tutors can 'force' students to study the Qur'an. They can ask the lecturers of Islamic courses to make the value of SAINS an integral part of the academic value of Islamic Education. This is of course a fairly noble job from the club's study activists.

It should have been a matter of helping teach the Qur'an, actually there were no problems with the tutors, even this was a very good activity. The problem is, according to the recognition of other activists, both from BEM and from LKIMB; besides teaching the Koran, through this SCIENCE student activists at the faculty level club introduced their religious understanding of students. The religious ideology adopted by activists at the faculty level is recognized as a salafi religious understanding (interview Ammar, 2015). Precisely is Salafi-Wahdah. I call this, because the club study group at the faculty level was under the guidance of Wahdah Islamiyah, an Islamic organization that had been known to develop many salafi ideas.

Wahdah Islamiyah himself during this time has declared himself a follower of ahlusunnah wal ala and salafus salih. However, this group of salafiyah crosses, in contrast to the existing salafiyah NU. Besides, they insist that only refer to the Qur'an and the Hadith, as well as this anti-tradition group. Even the religious festivals that have been traditionally enrolled in society such as mauled, tahlilan, barazanjian they think are trapped bid'ah. In many ways this group admires the 
understanding developed by Muhammad bin Abdul Wahab, which we later know as wahabiyah. Despite being admired by this, they did not want to admit that they were the followers of the Wahhabi. The admiration is reflected in the many major references they use from Ibn Taymiyyah who are widely referred to as Muhammad bin Abdul Wahab. besides they are also impressed with the Wahlian character like Abdullah bin Bazz.

Another pattern of religious beliefs developed by Wahdah Islamiyah is disagreeing with the ingenuity of tasawwuf. It is considered something innovative. They often hold discussions with the themes of the Tasawwuf understanding.

Against the different groups, especially Shiites, they tend to reject hard. They also can not accept the interpretation model of more contextual religion, especially by using western pracessors, using hermeneutics, for example. Even western scholars like pluralism, democracy and others can not be accepted by this group.

The group also wants this State to be based on the rules of the Shari'a formally and therefore their leaders are involved in the Islamic Law Enforcement Preparation Committee (KPPSI) of South Sulawesi. This Wahdah Islamiyah group is also very easily recognizable in its character. With pants on their ankles and usually keep the beards, this group looks different from other Muslims in Indonesia. 
What became the Salafi-Wahdah religious understanding became a characteristic, character and religious understanding of the Islamic club club study group at the Faculty level. This is what they quietly spread through the SCIENCE.

At the time of the implementation of SCIENCE their religious understanding had not received enough portion to convey to students, but the students began to be invited to continue their study of the Qur'an. They were invited to join the Al-Qur'an Lovers Community (KOMPAQ).

In the KOMPAQ they followed up on Qur'anic learning. In this group, they not only taught students to be good at reading the Koran but also began to give understanding. The tutors began to interpret the Qur'an in accordance with the understanding they had gotten from Wahdah or based on the translation of the Qur'an.

The study of the Qur'an was carried out in fardiyah preaching. This process is called persuasive preaching. Usually one person painstakingly guides 3 to 5 new students. Brotherhood guides men and sisters to guide women (Interview with Hamdani Harun, 2015).

At this level of the da'wah of fardiyah, students have not been emphasized on the questions of jurisprudence. They also have not been able to dance about the traditions and religious celebrations carried out by other Islamic groups. Although, for example, most of them have gained an understanding that religious activities are wrong, but they have not been directed to blame clearly. 
This was seen when Saharuddin, one of the students who had just joined this group, was asked about maulid and read barazanji. The answer; "read barazanji, it is a matter of the history of the prophet, it does not matter, only among Muslims there are many who make it the main thing in certain events that matter". The matter of maulid he stated; "Yes ... a group that wants to do it if there is a proposition, please, only we should follow a strong argument, the strong proposition that the Prophet copied" (Interview Saharuddin, 2015). It is like at this stage they are still shy to express themselves wrongly. It may be that at this stage they are also prohibited from commenting on khilafiyah, because their knowledge is still superficial.

In order for new students to be interested in participating in this activity, usually the supervisors offer help working on campus assignments for the student.

The next stage is to invite students to join taklim (taklim syar'i), they term it public preaching (Interview Ammar, 2015). The term taklim syar'i is also to show that this taklim is based on syar'I, for example not mixing mix of men and women.

Taklim Syar, as far as this is a kind of recitation with the themes of jurisprudence or aqeedah. Such activities also usually carry actual themes. In this kind of public preaching the ideas of what they consider to be the understanding of the Salaf are being introduced. 
The next stage is the cadre process (tarbiyah). This Tarbiyah is tiered; Starting from beginner, advanced and coach level (Overview Wahdah, 2014).

This stage is actually not specifically for students. But activists from the Islamic Studies Club of UNM, made Tarbiyah this as a place to continue guidance for students who had been recruited. Apart from this stage, his religious views are usually clearer and clearer. This picture can be seen from the statement of a senior activist who has followed the tarbiyah process. For him ikhtilaf is permissible but only based on the Qur'an and Hadith. That religious tradition, the senior student continued, was only two; Eid al-Fitr and Eid al-Ad'ha, the rest are reconciliation and heresy (interview Akmal, 2015).

Another interesting view from the Tarbiyah release cadres is the question of the Caliphate. For this matter they actually do not disagree with HTI. Brightly speaking, Akmal, one of the tarbiyah detainees, explained that the struggle for khilafah was also his ideal ideals. If there is a difference between them and other groups, it is only a matter of ways. For this group, according to Akmal, it will begin the struggle by first sowing the community, creating an Islamic society and then stepping into the next stage of the Khilafah State (interview Akmal, 2015).

The existence of the Salafi-Wahdah student group at UNM is quite strong. They master the faculties (especially da'wah institutions), conduct intensive coaching and control the campus mosques and mosques in the faculties. In 
addition, these activists got space in the SCIENCE program which was indeed formally applied in religious learning on campus. The great thing about this group, besides building a network between faculties and similar club studies. They also built a cross-university network in Makassar in the Islamic Study Group (Salaf). In this university network, well-known universities such as UNHAS, UIN, UMI, UNISMUH and UNM themselves are involved. This study group usually conducts recitations by bringing religious teachers from Wahdah Islamiah or from STIBA (College of Language Sciences) owned by Wahdah Islamiyah. In addition to recitation, this study group also conducted a consolidation and meeting on strategies in the process of recruiting students (Interview with Akmal, 2015).

Thus we can say; Although in terms of numbers if we want to compare the number of Muslim students at UNM, this salafi group is certainly not enough. However, their mastery of Islamic institutions or organizations in the campus, their role in religious learning and the intensification of their coaching activities, the actual religious discourse currently in the scope of UNM is mostly controlled by this Salafi-wahdah student group.

\section{Indonesian Muslim University (UMI) Makassar}

UMI is one of the largest private universities in South Sulawesi. Students who demand education at the College are from various parts of Eastern Indonesia. The development of Islamic organizations on campus is of course rapid, because it 
is indeed one of the largest private Islamic colleges in Eastern Indonesia. We can mention two of the most dominant Islamic organizations on this campus, namely PMII and HMI. Dominant because most of the cadres are indeed. Also dominant because it controls the Student Executive Board, at the University level or at the Faculty level. But in the context of Islamic discourse and mastery of campus missionary institutions, it seems that these two organizations are lacking if they do not want to say there is no role at all. Institutions that play a role in the latter context are called HTI, KAMMI and salafi-wahdah groups. Although this salafi group has not been as strong as that of HTI and KAMMI.

KAMMI or the Unity of Action for Indonesian Muslim Students, is quite significant on this campus. This organization began to develop in UMI after the reform period. Most KAMMI cadres are affiliated with the Prosperous Justice Party (PKS). Initially the affiliation was idiological. Therefore they made the PKS an idiological reference, including in their religious understandings which mostly referred to Ibn Taiymiyah and Hasan al-Bannah the founder of the Muslim Brotherhood. Obviously with religious references to these two figures, KAMMI's style of thinking and religious understanding leads to 'purification' of Islam. This group belongs to the category of revivalist Islam or in Imdadun Rahmat they are puritanical modernists, because many are influenced by Wahhabis (Imdadun Rahmat, 2007). 
Wahabiism emerged around the 18th century. This understanding was developed by Muhammad ibn Abd Wahab. He is the son of Abd Wahab, Uyaynah judge. This father is a follower of the school of Ahmad ibn Hambal (Abdurrahman Wahid, 2009). But Ustman ibn Abdullah ibn Baasyir stated that Abdul Wahab had different opinions with his son. In fact, since the beginning he felt a sign that he was wrong with Wahabi's understanding developed by his son (Wahid, 2009).

The understanding of the Wahhabis is not only literal, but also makes the text a closed corpus of other meanings. There is a monopoly on the meaning of the text. This is why the literalist developed by the Wahhabis cannot be equated with the literalist style of Ibn al-Arabi for example. If the literalist among the Wahhabi makes the corpus tightly closed, then in the literal hands of ibn al-Arabi it is open. If the first, besides maintaining textuality, also cannot open itself to see more meaning, the second, though still trying to maintain textuality, still tries to find a wealth of interpretations (Wahid, 2009). In addition, this notion also views different groups with the notion of being heretical and infidel (takfiri).

In understanding their nationality (if they are purely referring to the PKS) according to Imdadun Rahmat actually has a hidden agenda to replace the state foundation. At present there is not too much surface appearance, they only encourage the formalization of Islamic law and also fight for seven words in the first principle of the Jakarta Charter to reenter the first principle of the Pancasila (Imdad, 2009). 
However, in line with the PKS political development which experienced ups and downs and a declining image in the community, KAMMI at UMI no longer made it the main reference. Most of them only built personal affiliations with PKS politicians who also began to fragment with political interests. Because of that there seems to be a change in the way of the activists in the context of nationality. They consider that Pancasila is the basis of the State which should be maintained, although it still states that Islam and the State cannot be separated. They still want Islam to be formalized in the state order. In the matter of Islamic thought they also expressed their liking for the thoughts of Gusdur and Amin Rais (Interview Firman, 2015).

This KAMMI besides many of its members who entered the HMJ, also mastered the LDK Ashabul Kahfi. In the LDK, their ideas are socialized to students. The recruitment of cadres is done through regeneration in the LDK. It usually starts with instilling religious sentiments by getting prospective cadres to watch Palestinian films. Since the beginning of the orientation the group did master the LDK first. If tracked its history, PKS does indeed emerge from campus LDK groups. Because of that, at UMI, although LDK Ashabul Kahfi was founded by PMII activists, it was recently taken over by KAMMI. PMII activists themselves began to ignore LDK and were more active in intra organizations, such as HMJ and BEM. LDK is considered not too strategic in the context of campus politics. 
Besides through LDK, KAMMI also recruited multilevel recruitment systems. Murabbi, so the name of the cadre will look for 3-5 members to be a cadre, then the cadre will also look for members of that number to be cadre. Usually because of the cadre formation of the murabbi in the mosque (La Chen, 2015).At present KAMMI is sufficient to exist at UMI. They are quite capable of mingling with other students, including those with different organizations and even Islamic. This non-exclusive attitude from activist organizations made other activists, such as PMII or HMI, often invite them to work together. Even KAMMI was involved in the cipayung group, which consisted of PMII, HMI, IMM and Christian student organizations.

In addition to KAMMI, which is quite existent at UMI is HTI. Even HTI was originally developed at UMI in the 1990s. HTI was introduced by LDK activists who happened to be acquainted with HTI's thoughts when attending Arabic courses at IKIP Malang. The LDK activists then got to know more in Surabaya on the way back to Makassar (Syamsu Rizal, 2011). Since that time HTI has developed quite rapidly at UMI. They held regular discussions in the mosque and held mosques. The discussions are part of cadre training (tasykif).

Initially the recruitment process was carried out secretly, through interpersonal relations. If the student does not yet know the teachings of HTI, they begin to be built (Tasykif). Usually this development is continued with additional fardiyah and tsaqafah dirasah (Rizal, 2011). But there are those who already understand because they have 
previously participated in studies or even in cadres during high school, so when they entered UMI they were immediately picked up by their seniors. They just need to follow the advanced stages of cadre training (Interview with Arif, 2015).

In addition to discussions held in the courtyard of the mosque or at the campus mosque, HTI also conducts cadres in boarding houses. However, the intensive formation of HTI was carried out through LDK. They master the LDK called the Student Da'wah League (LDM), which is LDK which seems to be a challenger to LDK Ashabul Kahfi. Through this LDM, the regeneration process can be carried out intensively.

The activities of discussion and regeneration in the name of HTI in mosques and dikampus indeed cannot be carried out openly at this time following the issuance of a prohibition letter from the campus. Prohibition to use campus facilities in conducting activities. The ban itself according to UMI Chairman III Dr. Zein Irwanto was done because (Interview with Zein Irwanto, 2015):

1. One group that blatantly blaspheme other groups who do not agree with their ideas and that is very contrary to the academic tradition on the UMI campus which has always upheld tolerance and ukhuwa islamiyah. "We do not want these groups to blame each other and give the label of infidels, and those who often label the infidels are groups that are khilafah," explained Zein Irwanto.

2. In addition to being worried about damaging UKhuwa Islamiyah on the UMI campus, this understanding 
is also considered not to fit the campus vision where students are taught to learn to respect differences and unity, not to mutually forgive. Moreover, the UMI campus has its soul is ukwa islamiyah, with the principle of unity in the creed and mutual understanding in furuiyyah circles.

3. For the sake of the continuity of the culture of unity based on the sentence sawa.

But for HTI and Gemapem circles, this is not a problem. For them if they are forbidden to wear 'HTI' clothes, then they will come up with a discussion by not using HTI identity (Interview with Arif, 2015). Even to get around that they have prepared a seemingly neutral study forum called FOSIDI (Idiological Islamic Study Forum). They call it the HTI mantle organization, looks neutral but brings HTI ideas and ideology (Interview with Arif, 2015).

In this way, HTI discussion activities at UMI have continued intensively. This was also recognized by other students. La Chen, who is an activist at PMII and former KAMMI, admitted that the religious discussion rooms in UMI are currently filled with HTI groups and other salafiwahabi groups. In fact, this group is also active in writing writings on campus wall magazines, including being very active in distributing pamphlets, al-Ummah newspapers, bulletins and their magazines (interview La Chen, 2015). Their bulletin circulating when I was researching the campus was bulletin al-Islam with the theme Danger Behind Indonesian Islam (Da'wah Bulletin, $1436 \mathrm{H}$ ). While the magazine that was 
circulated was usually al-Wa'ie magazine, a magazine that was directly distributed from the center.

Another wing of HTI which is quite active at UMI is GEMA Liberation. This group eagerly raises issues about western imperialism in Indonesia by raising the facts in their frame. Various government policies, government systems and economic systems of this nation were criticized as part of the interests of western imperialism and colonialism. According to those who seem critical and selfish stand out compared to other groups. The real discourse is the arena of PMII children in the 90s-2000s which is now a discourse developed by HTI students through their GEMAPEM (interview Arif and Khalid, 2015).

Thus HTI in UMI even though it does not dominate dominantly the intra-campus institutions such as BEM but they are able to dominate religious discussion spaces. Even LDM, as an institution that is quite strategic in socializing religious ideas, has now been mastered. In short, although in terms of quantity, HTI is not the majority on this campus, they have now mastered religious discourse. If you want to say it is right, master the discourse. If you have reached the truth, then you have actually seized power. The will to power the will to Truth said Michel Fouchoul (Fuchoult, 2005).

\section{Hasanuddin University (UNHAS)}

Unhas is one of the leading universities in Indonesia with students from various places. Not only from eastern Indonesia, but also a lot from western Indonesia. Even from 
abroad there are also many who study on this campus. With students who are diverse and come from many circles, of course many student organizations are developing on this campus. Student-based Islamic organizations are competing to thrive on this red campus.

As in other campuses, HMI, PMII and IMM also have cadres here, however HMI is growing rapidly. Nevertheless the administrators of the Student Executive Board (BEM) are not representations of these extra organizations. They were elected not because of their Islamic affiliation. This also shows that in the intra-campus context, ideology or Islamic understanding does not determine. It's just that the development of the Islamic organization along with the ideas it adheres to affects Muslim students in Unhas enough to determine their religious orientation.

If at UIN, students can be more selective in choosing Islamic organizations because on average they already have prior religious knowledge (mostly from pesantren) so it is not the case with Unhas students. Like UNM, Islamic students on campus generally come from public schools that have not previously studied Islam more broadly. Especially if it is related to the history of the struggle between Islam and politics. Many of the Islamic students at Unhas do not understand the context. That's why they are easily influenced by Islamic organizations, especially if the organization and group are very expressive symbol of Islam. On the other hand the campus itself does not provide a limit, if you do not want to say no matter students want to take part in any Islamic 
organization. This may be a manifestation of freedom of association and assembly developed by Unhas towards its students.

So what organizations other than the three previously mentioned are developing in Unhas? It is none other than the most massive development and growth is the Mosque / Mushallah Lovers Student (MPM). This MPM group is guided by the salafi-wahdah group. Actually the management of the mosque was initially managed by students who understood the congregation. After that around 1988 (15 December 1988) until the late 1990s managed by the Dinul Islam Study Forum group, this group developed a lot of Shia ideology. But after that it was dominated by MPM which followed the religious flow of salafi-wahdah ... From the changing management of campus mosques from various religious groups, it showed how open the campus was with various religious ideas that developed.

Associated with religious understanding this group does not need to be reviewed in depth because there are similarities with the study club or the Faculty level LDK at UNM. But in some cases, for example, about our system of government; MPM activists stated that this government system must be changed slowly towards the khilafah system (Rizky's interview, 2015). This student group also firmly gave birth to all the religious traditions of the Islamic community which were considered to be mixed with tradition.

The MPM group also controls campus mosques and 11 other faculties. They also master campus LDK and other 
faculty LDKs. The process of study and regeneration they routinely do with stages; fardiyah da'wah, including students in the Shari'ah Taklim to Tarbiyah in three levels (This is similar to UNM). This group is quite interesting for some students because it is considered to be more idiological Islam and in daily life it also follows the sunnah of the Prophet in a clear manner. Besides that because their bulletins are also routinely distributed in mosques as student reading material. Other bulletins that are considered not in line with their religious understanding are not allowed to be circulated in the mosque they handle. Especially if the Islamic bulletin is considered to smell or lift liberal ideas. Therefore they dominated religious discourse through the writings they spread.

In addition to MPM, HTI also developed quite rapidly at the Unhas campus, especially in the Engineering faculty. This group dominated the religious and intellectual discourse in the engineering faculty. Khalid, the GEMAPEM board explained that through GEMAPEM the discourse carried out by HTI could be well socialized to the children of the engineering faculty (Interview Khalid, 2015). This Gemapem has an agenda:

a. Weekend release dialogue

b. Discussing GARIS (Ideas for Revolutionary Strategies) in this discussion usually raises developing issues

c. Dialogika (discussion of strategic matters

d. Political Visits to other movement institutions. 
In addition, this group also conducts exemption training on campus, at least 3 times a year. Regular activities carried out by HTI activists, both through the HTI chapter in Unhas and with Gemapem, have made this organization quite influential in Islamic discourse and religious discussions at Unhas.

Of course with the development of these two organizations on the Unhas campus, it is not enough to say that this campus has shifted massively to its religious understanding. Because the dominant students are not too concerned with various religious issues. The students themselves if there are indeed professional-oriented maps. This type of student only emphasizes how to finish and professional in their field. There are proletarian activists. This type is a type of student who deals with the world of activism and even mentoring for marginalized communities. There is a type of hedonist, namely students who only interpret the world as a world of rah-rah. Lastly there were religious accidents. The type is happy with worship alone without wanting to be active in the world of activism that is synonymous with demonstrations and various political movements.

The influence of the two religious understandings (MPM and HTI) that developed in Unhas is more on students who are of the aksetism-religious type. This type feels compatible with the idea developed by MPM or HTI. If MPM is in accordance with its orientation to carry out rituals perfectly, then HTI offers how to Islam in a 'perfect' manner, 
including within the political framework of the state. Some who are professional oriented are also interested in participating, besides because they also have no activity in the world of activism as well because they usually view religious issues in black and white, just as MPM and HTI offer. Because it is understandable if these understandings develop a lot in the faculty of engineering (HTI) and medicine and Public Health (MPM).

\section{Shift in Religious Understanding or Islamic Awakening;} A reflection

From the various new religious ideas that developed on campus, it was seen that this group gripped the campus with several models; some are still vague but slowly begin to master the religious discourse, some have mastered certain institutions on campus and some have not mastered campus institutions much but have mastered religious discourse on the campus. Even though with some models of mastery, the indications of a shift in religious understanding in several campuses are already visible. The most obvious is of course the process of infiltration of ideas that are different from the usual ones to campus institutions.

Why is it considered a new or different ideology? First; Of the several religious ideas that infiltrated the campus clearly they can indeed be regarded as salaf-wahabii, especially in the sense of Al-Ayubi, where this group tends to doctrinal dogmatism, scripturalism and always returns to authentic Islamic sources. Besides literalist-scriptualists, it is also difficult to accept different understandings (Ayyubi, 1991). 
More extreme than this notion is the desire to change the foundation of the State and crave Indonesia to become a Caliphate State.

Then is this new in the Indonesian context? Actually no. Salafi is a part of religious understanding that is common in Indonesia. Even the largest Islamic organization NU, also adheres to this salafi. It's just that the salafi adopted by the NU is not the same as the salafi context intended above. In addition to salafi NU knows the school also because of the attitude of tawasuth and tasammuh which is his trademark. And of course the understanding of salafi which is known in the body of NU does not marginalize tradition with the principle of al-Adah Muhakkamun.

That in its history, several Islamic groups also emerged with fundamentalist attitudes including having the desire to make the Indonesian state an Islamic state. But in the long history of our country, these fundamentalist understandings change with dialogue with various ideologies, traditions and national dynamics. Because of this, its emergence is now believed by some researchers to be related to transnational interests. It is no longer merely an upheaval in the Indonesian context.

According to the study of Greg Fealy and Bubalo, there are three mainstream Islamic movements of this kind. First, Muslim brothers and sisters. Second, salafi groups. This group is mostly based on da'wah and education institutions. Third, the jihadi group. This group is the most extreme group of Islamist movements that legitimize violence like suicide 
bombings (Fealy, 2007). In his study Fealy described the movements of the three main fundamentalist Islamic movements in Indonesia, all networked or had outgoing relationships. In short this movement is a transnational movement.

But does anyone claim that this is precisely part of the rise of Islam? L Esposito, for example, considers this is not an attitude of fundamentalism, because fundamentalism is actually a Christian character that is forced into Islam. Strictly speaking, according to L Esposito, this is the rise of Islam (Islamic revivalism). In line with Esposito, other orientalists like Youssef Choeiri and Volt also speak the same (Imdad, 2007).

But for me the category of Islamic revival is only words that wear the Orientalists; because what is meant is the character of Islam that is far from cosmopolitan. The character of the scriptualist, returning to the original and antiIslamic Islam is very prominent in the Islamic revivalist. Indeed there is a door to ijtihad, but ijtihad which is intended in the framework of non-culture and without a school which is actually where Islamic intellectual property is.

As previously revealed in the course of the history of Islam in Indonesia, this type of Islam was ultimately not prevalent in the archipelago. Because of this, the emergence of such ideas in the midst of students, as previously explained is clearly a form of Islamic understanding. Moreover, some of these understandings refer to their interests not in the context 
of our nationality, but rather in the interests of (political) outside groups.

Shifting identities, including shifts in certain understandings, are commonplace in the context of globalization. The process of moving people and also ideological moving / identity is very possible with the opening of the world. With the possibility of the wild movement of ideology and identity, it also encourages the possibility of someone changing their way of representing themselves, including in religious understanding. This is what happens among some Indonesian Muslims. This includes some Islamic students as reflected in this study. But at the same time from the inside there is usually a stretch of backflow towards the tendency. Backflow that wants to address their distinctive identity. This is the process of globalization-glocalization.

This paper is indeed only photographing the shifting tendency resulting from globalization. That there is a phenomenon which is a world trend that occurs also in Indonesia. As long as the change does not have a negative impact on the peaceful life of the community, it does not matter. Unfortunately what is displayed in our lives today is not as good as we hoped it would be. Conflict, violence and acts of intolerance in the name of religion are a common sight. One that is suspected of escalating this is the emergence of this new understanding.

It is important to emphasize, that now it is important to reiterate the unique Islamic style of the archipelago, while at the same time rebuilding our national commitment. Islam 
Nusantara in a simple language is a more soft Islamic and religious identity, tolerant or borrowing Azra's term "flowery Islam." We hope that with this Islamic model we can navigate the life of this increasingly dark and unpredictable world.

\section{References}

Ahmed Annaim, Abdullah. Terj Sri Murniati, Islam dan Negara Sekuler. Bandung : Mizan; 2007 al-Bashirah 05 Tahun II, 2007

Amstrong, Karen. What is Fundamentalism. Makalah Intolerance and Fundamnetalism Seminar. 26 Januari 2005

Annabhani, Taqiyuddin, Daulah Islam. Jakarta: HTI Press, Ayubi, Nazih., Political Islam: Religion and Politics in the Arab World London and New York: Routledge, 1991

Bahaya Di balik Islam Indonesia. Buletin Dakwah al-Islam HTI Edisi 759/Th.XXII/1436H

Baso, Ahmad, Neo Liberalisme Cak Nur Vs Pribumisasi Gusdur. Makalah tahun 2005

Castells, Manuel., The Power Of Identity. Oxford: Blackwell, 1997 
El Fadl, Khaled Abou., The Great Theft, Wrestling Islam From the Extremist. San Fransisco : Harper San Fransisco, 2005

Fealy, Greg dan Anthony Bubalo., Jejak Kafilah: Pengaruh Radikalisme Timur Tengah di Indonesia. terj, Bandung; Mizan, 2007

Hasan, Aswar, Quo Vadis KPPSI, (Artikel; Harian Fajar, 4 Januari 2002)

Jurdi, Syarifuddin., Pemikiran Politik Islam Indonesia: Pertautan Negara, Khilafah, Masyarakat Madani dan

Demokrasi. Yogyakarta : Pustaka Pelajar, 2008

M.Ja'far, Alamsyah (ed)., Agama dan Pergeseran Representasi:

Konflik dan rekonsiliasi di Indonesia. Jakarta : Wahid Institute, 2009

Madjid, Nurcholis. Islam kemodernan dan Keindonesiaan.Bandung : Mizan, 1987

Menghalau Radikalisme Kaum Muda: Gagasan dan Aksi. Jurnal Maarif Vol.8 N0.1: 1 Juli 2013

Moloney, Gail and Ian Walker. Social Representation and Identity:

Content, Process and Power. New York : Palgrave Macmilan, 2007

Mufid, Ahmad Syafi'I, Perkembangan Paham Keagamaan Transnasional di Indonesia. Jakarta : PUSLITBANG Kehidupan Keagmaan; 2011,

Rahmat, Imdadun, Arus Baru Islam Radikal; Transmisi Islam Revivalisme Timur Tengah ke Indonesia. Jakarta : Erlangga; 2007 
Rahmat, Imdadun, Idiologi Politik PKS; Dari Masjid Kampus ke Gedung Parlemen. Yogyakarta: LKiS; 2007

Ridjal, Tadjoer., "Metode Bricolage dalam Penelitian Sosial" dalam Burhan Bungin $(E d)<$ Metodologi Penelitian Kualitatif .Jakarta: Raja Grafindo, Cet-III,2004

Rizal, Syamsu, "Jaringan Hizbut Tahrir Indonesia di Kotakota Makassar Sul-sel". Dalam Ahmad Syafi'I Mufid, Perkembangan Paham Keagamaan Transnasional di Indonesia. Jakarta : PUSLITBANG Kehidupan Keagmaan; 2011,

Rumadi., "Pandemi Idiologi Puritanisme Agama" dalam Alamsyah M.Ja'far (ed), Agama dan Pergeseran Representasi: Konflik dan rekonsiliasi di Indonesia. Jakarta : Wahid Institute, 2009

Selayang Pandang Wahdah Islamiyah. Makassar: Departemen Informasi dan Komunikasi Wahdah Islamiyah;Edisi II-2004.

Spradley, James P., Metode Etnografi. Yogyakarta: PT Tiara Wacana, 1997

Sudikan, Setya Yuwana., "Ragam Metode Pengumpulan data: Mengulas Kembali Pengamatan, Wawancara, Analisis Life History, Analisis Folklor" dalam Burhan Bungin (Ed) Metodologi Penelitian Kuantitatif . Jakarta: PT Raja Grafindo Persada; cet-III, 2004 Syafii Mufid, Ahmad (ed)., Perkembangan Paham Keagamaan Transnasional di Indonesia. Jakarta; Badan Litbang dan Diklat, 2011 
Wahid, Abdurrahman (ed)," Musuh dalam Selimut" dalam Abdurrahman Wahid, Ilusi Negara islam. Jakarta: The Wahid-GBTI-Maarif, 2009

Wahid, Abdurrahman dkk. Ilusi Negara Islam. Jakarta : GBTIWI-Maarif Institute. 2009,

Woodward, Kathryn. Identity and Difference. London : SAGE Publication, 1997

Yavus, Hakan. Islamic Political in Turkey. New York : Oxford University Press, 2003. 